\title{
DECONVOLUÇÃO PREDITIVA MULTICANAL DE REFLEXÕES MÚLTIPLAS NO DOMÍNIO CRS
}

\author{
Rosangela Corrêa Maciel \\ Orientador: Dr. Milton José Porsani (UFBA) \\ 82 p. - Tese (Doutorado) - Defesa 06.07.2007
}

RESUMO. No processamento de dados sísmicos as reflexões múltiplas são normalmente tratadas como ruído. Sua presença cria sérias dificuldades tanto ao processamento quanto para a interpretação, prejudicando a qualidade e a confiabilidade das seções sísmicas. No presente trabalho, testamos uma nova metodologia para a atenuação de reflexões múltiplas. A nova abordagem explora e combina a robustez do método de deconvolução direta multicanal, tipo Wiener-Levinson, com o método de empilhamento sísmico conhecido como CRS (Common Reflection Surface). Ambos exploram a redundância e correlação espacial das reflexões primárias e múltiplas dos dados sísmicos. A periodicidade dos eventos correspondentes às reflexões múltiplas é crucial para o sucesso da deconvolução preditiva. Infelizmente esta condição não se verifica nos dados adquiridos nos levantamentos sísmicos. Para contornar esta limitação a deconvolução preditiva multicanal foi aplicada em dados corrigidos de NMO-CRS. Pois desta forma a periodicidade das múltiplas é melhor preservada e o método de deconvolução preditiva resulta mais efetivo. A deconvolução preditiva multicanal foi aplicada sobre grupo de traços adjacentes, tomados ao redor de cada traço do levantamento. A este modo de aplicar a deconvolução, utilizando traços de afastamento comum, juntamente com traços de ponto-médio comum, denominamos de deconvolução areal. 0 novo procedimento de filtragem foi testado sobre dados sísmicos sintéticos e reais. Utilizamos os dados sísmicos do Golfo do México que é bastante abundante em múltiplas do fundo do mar, do topo e da base do sal, além de múltiplas internas. Essa filtragem foi aplicada em cascata visando atenuar um evento de cada vez, tendo-se iniciado com a atenuação das múltiplas do fundo do mar, seguido das múltiplas do topo do sal e da base do sal. Os resultados obtidos são bastante satisfatórios e demonstram que a nova abordagem é robusta e também eficaz na atenuação de reflexões múltiplas.

ABSTRACT. In seismic data processing the multiple reflections are normally treated as noise. Their presence creates serious difficulties both to the processing and to the interpretation, hindering the quality and reliability of the seismic imaging of the subsurface. This work proposes a new methodology for the attenuation of multiple reflections. The new approach explores and combines the robustness of a Wiener-Levinson type direct multichannel deconvolution method, and the seismic stacking method known as CRS (Common Reflection Surface). Both explore redundancy and spacial correlation of the primary and multiple reflections of the seismic data. The periodicity of the multiple events is crucial for the success of the predictive deconvolution method. Unfortunately that condition does not hold true in real seismic data. To bypass that inconvenience we used seismic corrected whit NMO-CRS. In such a way the periodicity is better preserved and the predictive deconvolution method can be more effective. The multichannel predictive deconvolution was applied to the group of contiguous traces, collected around each target trace. We called this way of applying multichannel deconvolution, by collecting traces from both common-offset (CO) and common mid-point (CMP) domains 'spacial multichannel deconvolution'. The new approach was tested by using synthetic and real seismic data from the Gulf of Mexico which is full of multiples of several types. The multichannel filtering was applied in cascade, attenuating first the ocean bottom multiples, followed by the multiples associated to the top of the salt and finally, by attenuating the multiples corresponding to the bottom of the salt. Numerical examples show that the results are quite satisfactory, thus demonstrating that the new filtering approach is robust and effective for attenuation of multiple reflections. 